Pak. Journal of Int'L Affairs, Vol 4, Issue 3 (2021) Social Issues of Pakistan: Narrative of the U.S. ...

\title{
SOCIAL ISSUES OF PAKISTAN: NARRATIVE OF THE U.S. MAINSTREAM PRESS DURING BIDEN'S FIRST YEAR OF VICE PRESIDENCY
}

\author{
Awais H. Gillani \\ Assistant Professor \\ Department of Media Studies \\ The Islamia University of Bahawalpur \\ Bahawalpur - Pakistan \\ Corresponding Author*ahgillani@iub.edu.pk \\ Noman Ishfaq \\ M. Phil. Scholar \\ Department of Media Studies \\ The Islamia University of Bahawalpur \\ Bahawalpur - Pakistan \\ nomanishfaq786@gmail.com \\ Gulala Pirzada \\ M. Phil. Scholar \\ Department of Media Studies \\ The Islamia University of Bahawalpur \\ Bahawalpur - Pakistan \\ gulalahaseeb@yahoo.com
}

\begin{abstract}
American policy towards Muslims seems to change with Joe Biden's lift of the Muslim ban imposed by President Trump. This study aims to see how the U.S. media was creating a narrative, perception, and public opinion about the social issues of Pakistan during the first year of the Vice Presidency of Joe Biden - January 2009 to January 2010. The study also wants to find out the connection between the U.S. foreign policy and press coverage of Pakistan during the War on Terror. Employing thematic analysis and agenda setting theory, the study analyses the front-page stories of mainstream American printed press from January 2009 to January 2010. The study finds that the U.S. leading press was working as a fourth branch of the government to support American foreign policy objectives by spreading false narratives and perceptions about Pakistan to force Pakistan to cooperate with the U.S. War on Terror in Afghanistan.
\end{abstract}




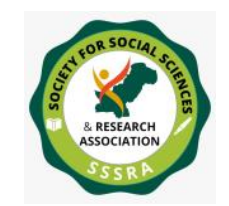

Pak. Journal of Int'L Affairs, Vol 4, Issue 3 (2021) Social Issues of Pakistan: Narrative of the U.S. ...

This study adds to the Agenda-setting theory, conflict communication, and propaganda studies.

Key words: Pakistan, Education, Law, Art, Human rights, Liberal and Conservative, American newspapers, Madrasa, Muslim society, Joe Biden.

\section{1: Introduction}

Media images and narratives saturate the world we are living in. These narratives create myths, stereotypes, images, symbols, metaphors, signs, and fake news. Narratives assign specific meanings to objects, which may become public knowledge, yet reality may diverge from the narrative and general knowledge (see, Lowenthal, 1961; Roßmann, 2021). Here comes Lippmann, who said "We are all captives of the picture in our headour belief that the world we have experienced is the world that really exists" (Arts, 1982, p. 22). Specific meanings get associated with certain symbols and objects, and these meanings influence our thoughts and opinions. Narratives help to create a perception that creates pictures in our heads. Lowenthal (1961) says, "The most direct and composite experience of the world is a composite of perception, memory, logic and faith." Media develop our perceptions, make them fix in our memory, create logic in those perceptions by linking them with day-to-day coverage of events under a certain ulterior agenda and win people's faith by exploiting their emotions, ideologies, needs, desires and, fears.

Countries create national narratives to protect their interests or create competing narratives to counter the opposing narratives. The American twin towers were the symbol of business, but the tragic incident of 9/11 made them a symbol as a victim of global terrorism or Islamic terrorism. America launched War on Terror (WOT) based on the terror narrative associated with the twin towers' destruction. With the power of narrativevisual, oral, comic, written - the symbol of American business and wealth made a symbol of the victim of global terrorism. Using the narrative of WOT, the U.S. launched its longest war in history in which Pakistani society had to participate under American pressure at the cost of its socio-economic fabric. Pakistan and the people of Pakistan could not counter the American narrative of WOT. the U.S. narrative building machinery demonized Pakistan and Pakistani people and institutions. American media framed the picture in the heads of the American and global population that terrorism lies in Pakistani "DNA" (see, Gillani \& Zhou, 2015a, 2015b).

The world of narrative is dangerous and a double-edged sword; it can either make or break. Joe Biden as a presidential candidate, wants to re-build broken relations to the extent that he not only promises to lift President Trump's "Muslim ban" from "day one" in 


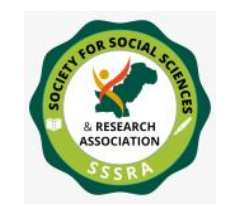

Pak. Journal of Int'L Affairs, Vol 4, Issue 3 (2021) Social Issues of Pakistan: Narrative of the U.S. ...

the Oval office but also he promises to make Muslims a part of his cabinet (Khalid, 2020). Mirza \& Mushtaq (2019) note that both in public and government, a transformational shift in narrative and action is taking place in Pakistan, and "Russo-Chinese active support for Pakistan could create a paradigm shift in the coming years." Explaining the cause of this transformational shift, the writers explain that Pak-US were protagonists since the creation of Pakistan. And both the countries benefitted from each other. Yet, after the U.S. invasion of Afghanistan, Pak-US relations soured in the wake of American counterterrorism operations in South Asia, and both countries became the antagonist (Mirza \& Mushtaq, 2019).

This study aims to see what social issue of Pakistan the U.S. mainstream printed press is reporting on the front page from January 2009 to January 2010. What narrative is the mainstream U.S. press creating about Pakistan's social issues, and what message are the global audiences drawing from these narratives? Are they creating myths, fake news, hyperbole, and fake news about Pakistan under the agenda to force Pakistan to bow in front of American demands to cooperate in the U.S. led WOT at the cost of Pakistan's socioeconomic-political-security fabric.

\section{2: Literature Review}

\section{1: Inept and Biased Experts on Pakistan in American Media and Academia}

Sparrebom says that most newspapers' headlines cannot afford to probe deeper into underlying problems (see, Sparrebom, 2008, Autumn, p. 2). Lieten (2008, Autumn, p. 3 ) in the article 'Pakistan, an abundance of problems and scant knowledge' relates:

Stephen Cohen (2004) had warned: the U.S., in the midst of the war against terror in that region has 'only a few true Pakistan experts and knows remarkably little about the country. Much of what has been written is palpably wrong, or at best superficial.

Republicans own most of the U.S. media (American Foreign Relation, 2021); hence they are very conservative. Eisinger, Veenstra, and Koehn (2007) relate that The New York Times' columnist, Pual Krugman, writes that compared to their foreign counterparts, "the 'liberal' U.S. media are strikingly conservative. The conservative press in America looks Islam with askance and biasness i.e. coverage biasness and statement biasness. CNN's senior political correspondent Candy Crowley, "admits": 


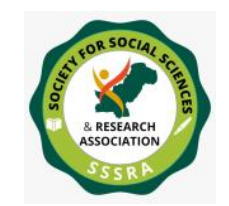

Pak. Journal of Int'L Affairs, Vol 4, Issue 3 (2021) Social Issues of Pakistan: Narrative of the U.S. ...

We are a bag of biases, I know what my biases are and where they come from, and as a reporter it is important to know and be aware of your biases and factor on your own prejudices when covering a story; the problem is that many reporters won't do that (see, Eisinger et al., 2007).

\section{2: Lippmann's Pictures in the head Phenomenon}

To understand pictures in the head phenomenon, one must go to Walter Lippmann - father of modern American journalism. Lippmann defines stereotypes as:

“distorted picture or image in a person's mind, not based on personal experience, but derived culturally" ... Lippmann reasoned that the formation of stereotypes is driven by social, political, and economic motivations, and as they are passed from one generation to the next, they can become quite pervasive and resistant to change. "The only feeling that anyone can have about an event he does not experience is the feeling aroused by his mental image of that event." (see, TEACHING THE MIDDLE EAST - A RESOURCE FOR EDUCATORS, 2010a).

Teaching about Islam and Muslims in American schools and colleges is highly challenging because American youth does not accept the fact or actual reality about Muslims that is contrary to their own belief and they like to keep distance from Arabs and Pakistani children and youth (TEACHING THE MIDDLE EAST - A RESOURCE FOR EDUCATORS, 2010a; Winnick, 2019).

TEACHING THE MIDDLE EAST - A RESOURCE FOR EDUCATORS (2010b) relates:

From roughly 1985 to 1995 , I traveled across the United States and spoke to a variety of Americans about Islamic history and culture. In order to evaluate the attitudes and prejudices of my various audiences, I asked them to participate in the following exercise before giving my presentation. I asked them to imagine and write down what words they associated with "Muslim," "Islam," "Arab," or "Middle East." After collecting nearly 5,000 sheets of responses, it was apparent that the overwhelming majority of the words carried negative, pejorative, or insulting connotations. Here are some examples: aggressive, angry, barbaric, cruel, extremists, fanatic, greedy, hate, holy war, killers, mistreat women, oil, oppressive, patriarchal, radical, sleazy, subservient females, terrorist, uncivilized, unclean, unstable, violent, warlike, zealots. 


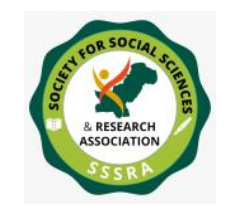

Pak. Journal of Int'L Affairs, Vol 4, Issue 3 (2021) Social Issues of Pakistan: Narrative of the U.S. ...

Pew Research Center (2017) reports that "75 \% Muslims" in America face discrimination, and "50\%" Muslims believe that life for them is getting complicated in the United States, whereas 9 out of 10 Muslims feel proud to be American. The American melting pot is not letting Muslims become part of mainstream America as "62\%" American Muslims do not feel like a part of mainstream American society (see, Pew Research Center, 2017).

\section{3: Agenda Setting, Narrative and Stereotyping}

Cohen, who defining the agenda-setting said that the press may not force people what to think, but it is "stunningly successful "in telling people what to think about" (Dearing \& Rogers, 1996). Many studies and surveys inform that Americans are not much aware of world affairs, the only window through which they see the world is media. Keeping the literature in view, it is clear that narrative in the U.S. is anti-Muslim and stereotyping against Muslims is common in all walks of American life-from school children to politicians-hence according to Lowenthal (1961), "Human survival is in danger if there is no considerable correspondence between the world that people conceive and "it actually is." Stereotypes have an impact on how we see and remember the world. Americans have negative views about Muslims and Pakistanis because "the most direct and simple experience of the world is a composite of perception, memory, logic, and faith" (see, Lowenthal, 1961).

Explaining the "Agenda-setting function of mass media, McCombs \& Shaw (1972) relate:

In choosing and displaying news, editors, newsroom staff, and broadcasters play an important part in shaping political reality. Readers learn not only about a given issue, but also how much importance to attach to that issue from the amount of information in a news story and its position. In reflecting what candidates are saying during a campaign, the mass media may well determine the important issues - that is, the media may set the "agenda" of the campaign (McCombs \& Shaw, 1972).

American's complete reliance on mass media machines to see the outer world is highly unrealistic as Howard Beale - a fictional character from the film Network (1976) tells people that T.V. is an amusement park and T.V. will not tell $u$ the truth; instead, it will keep you in an illusion - a fantasy and a false reality (see, Lumet, 1976). Lowenthal (1961) explains that "A purely visual world would also be a usual abstraction; a concrete and stable sense of the milieu depends on synthesia, sight combined with sound and touch." 


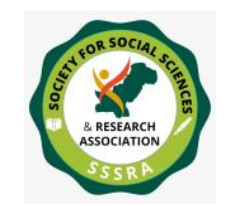

Pak. Journal of Int'L Affairs, Vol 4, Issue 3 (2021) Social Issues of Pakistan: Narrative of the U.S. ...

Americans are distracted and misinformed by the media. They need to get in touch with the Muslim and Muslim world to test the validity and reality of their stereotypes; otherwise, the United States will keep waging wars in distant lands taking advantage of the ignorance of American people and xenophobia will increase in the American society.

\section{4: Agenda of American Media and Government: Criticize Pakistan}

During the presidency and Vice Presidency of Joe Biden, the mainstream U.S. media report that if Pakistan will not cooperate in WOT, it will face less criticism in media. In the case of Pakistan, media, the U.S. government, political parties are exerting a consolidated and concentrated power to force Pakistan to bow in front of American demands - to cooperate in the WOT according to the wish and will of the United States. In the case of Pakistan, the agenda of the American media is the agenda of American foreign policy, and the media is working as a fourth branch of the government to extend the designs and influence of the state beyond its borders (see, Beattie, 2019, p. 165; Jia \& Lu, 2021).

The mainstream U.S. press reports that Pakistan's role and help is vital and central in the American war in Afghanistan; this is why White House spokesman Robert Gibbs said about Pakistan that "Obviously, it demonstrates we've still got work to do" (DeYoung $\&$ Wilson, 2009). The mainstream American press admits that growing involvement of the U.S. in Pakistan and the South Asia region is generating a great mistrust but in the same front-page news report the mainstream newspaper report that "It's going to be a game of cat-and-mouse with them for a while," another official said, adding that "what we're trying to do is to force them to recalculate" where their advantage lies" (see, DeYoung, 2009a). In reaction to American policies and pressure tactics, a Pakistani official says, "What are the Americans trying to do, micromanage our politics?" a senior Pakistani official said testily. "This is not South Vietnam"” (DeYoung, 2009b).

In response of Pakistan's cooperation with the U.S. in its WOT in Afghanistan, Secretary of State Hillary Rodham Clinton offers Pakistan "more public praise and less public criticism" (DeYoung, 2009a). The mainstream U.S. press very categorically shares American policy towards Pakistan with global and American audiences as "President Obama has offered Pakistan an expanded strategic partnership, including additional military and economic cooperation, while warning with unusual bluntness that its use of insurgent groups to pursue policy goals "cannot continue" (DeYoung, 2009a).

\section{3: Data, Methodology, and Theoretical Framework}




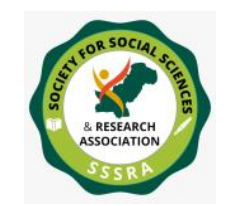

Pak. Journal of Int'L Affairs, Vol 4, Issue 3 (2021) Social Issues of Pakistan: Narrative of the U.S. ...

\section{1: Data}

This study analyzes front-page stories of three mainstream U.S. dailies-The New York Times, The Washington Post and The Wall Street Journal-published during the first year of the Vice Presidency of Joe Biden from January 2009 to January 2010. The frontpage stories of the two leading U.S. dailies-The New York Times and The Washington Post-were accessed from the ProQuest National Newspapers database by putting the search word "Pakistan" in the search box and choosing front-page stories only option with a time limit from January 2009 to January 2010. The Wall Street Journal's front-page stories were accessed from the LexisNexis database by putting "Pakistan" in the search box with a time limit from January 2009 to January 2010. The three mainstream U.S. newspapers published 119 stories on their front pages from January 2009 to January 2010. The New York Times published 73 news stories, The Washington Post published 33 news stories, and The Wall Street Journal published 13 news stories.

\section{2: Methodology}

This study applies Thematic Analysis for identifying and analyzing patterns to uncover the coverage pattern of the social issue Pakistan on the front pages of American mainstream dailies from January 2009 to January 2010 during the first year of the first term Vice Presidency of Joe Biden. To identify "recurring patterns of meaning," thematic analysis can be used to build themes and arguments across a data set (see, Braun \& Clarke, 2006). The data corpus is studied to create a comprehensive thematic description of the most critical and prevalent themes and patterns.

The study is inductive. Themes are discovered at the explicit and latent level to describe, interpret, and examine underlying ideas, assumptions, and conceptualizations in the data corpus of front-page stories using the theoretical framework. The data was coded in the light of research questions and theoretical framework-Agenda-setting.

\section{3: Theoretical Framework}

Cohen defining the agenda-setting said that the press may not force people what to think, but it is "stunningly successful "in telling people what to think about" (Dearing \& Rogers, 1996). Studies show that out of their biases, it is the agenda of the mainstream American press to malign, defame and shame Pakistan to create a negative narrative about Pakistan in the world (see, Gillani \& Zhou, 2015a, 2015b; Khan, 2008; Moeller, 2007) to fulfill American foreign policy objectives. 


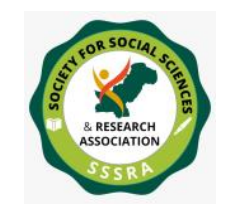

Pak. Journal of Int'L Affairs, Vol 4, Issue 3 (2021) Social Issues of Pakistan: Narrative of the U.S. ...

\section{4: Thematic Findings of the Social Issues of Pakistan}

\section{1: Worsening Law and Order Situation in Pakistan: World's Safety is at Stake}

On the front pages of the leading U.S. newspapers, Pakistan is presented as a country where law and order are non-existent; and the government has failed to control the militancy, especially in Swat and the related areas that the militants occupied after the truce (Perlez, 2009a). The top administration was worried about worsening law and order situation as The New York Times' front-page story of April 23, 2009 publishes the statement of Secretary Clinton as: "deterioration of security in nuclear-armed Pakistan 'poses a mortal threat to the security and safety of our country and the world" (Perlez, 2009c). Along with the political, moral, religious narrative, the security narrative was also a dominant theme of the leading press.

On January 6, 2009, The Wall Street Journal publishes a front-page story-For Middle-Class Pakistanis, A Gun Is a Must-Have Accessory --- With Kidnappings and Violence on the Rise, Demand for Weapons Permits Grows - and paints a very horrific picture of Pakistani society and government where law and order do not exist, corruption is at peak and military city of Rawalpindi that is just half an hour drive from Islamabad is replete with licensed arms shops near, "Liaquat National Bagh -- the park where Pakistan's first prime minister was assassinated a half-century ago and where Ms. Bhutto was killed last December -- small arms shops, their walls lined with shotguns and long-barreled pistols, are scattered amid mom-and-pop stores" (Wonacott, 2009). The paper very craftily has left a thought that Pakistan from the very beginning is "incubator of militants," because those who killed Liaqat Ali khan have also killed Miss Bhutto, yet still, Pakistan and Pakistanis are not leaving the path of militancy (Wonacott, 2009). A common who is unaware of Pakistan and its history and culture will easily become prey to American media's propaganda.

The leading press portrayed that Pakistan's civil and criminal courts have been corrupted to the extent that militants have no fear of law; instead, courts give them protection just because of fear. The front-page story of The New York Times - published on August 6, 2009, under the title '70 Murders, Yet Close to going free in Pakistan'-tells about Malik Ishaq who has killed 70 shitte Muslims and Hafiz Saeed-leader of LashkahrI-Taiba - has killed more than 160 people and he is the key person behind Mumbai terror attacks, but even then the Supreme Court of Pakistan and the Lahore High Court released these criminals (see, Tavernise \& Gillani, 2009). It is told in the story that the release of Malik Ishaq from the Supreme Court of Pakistan was "as obvious as the day light" (Tavernise \& Gillani, 2009). The story further tells about a judge who tried more than 90 


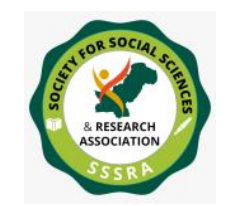

Pak. Journal of Int'L Affairs, Vol 4, Issue 3 (2021) Social Issues of Pakistan: Narrative of the U.S. ...

terrorism case but, "His guilty verdicts were overturned so frequently ... that once he met a man whom he had sentenced to death who was instead working as a collector in bus" and the very judge used "16 different licensed plates to avoid being followed" (Tavernise \& Gillani, 2009).

\subsection{1: Taliban: Fueling Terror and Militancy}

The New York Times' front-page story-In Pakistan, Radio Amplifies Terror of Taliban - says that the Taliban by using radio are inflicting terror upon people (Jr. \& Shah, 2009). The Taliban leaders, by using radio, "outlines newly proscribed "un-Islamic" activities in Swat, like selling DVDs, watching cable television, singing, and dancing, criticizing the Taliban, shaving beards, and allowing girls to attend school" (Jr. \& Shah, 2009). Rosenberg and Hussain (2009) report in The Wall Street Journal that "Pakistan is facing rising militant insurgency and stuttering economy" later it is told in the leading press that insurgents in Swat are beheading people, "setting donkeys on fire," "locking women inside home."; and are using the main square of Swat, which is known as "slaughter square" to dump the dead bodies of those who oppose them. The incident of flogging the girl in the FATA area is repeated five times in the leading press.

Drilling the same thought again and again is important for propaganda and to make people believe that America's cause is noble in Pakistan the same way like during SpanishAmerican war of 1898. Describing the extreme brutality of militants in Swat, the leading press gives a pictorial depiction of human slaughter by using an eye witness who said that:

"I saw the blood gushing from his throat, I saw him squirming like a chicken. Even today I see it and I cannot sleep," Khan said. The next morning, the headless body lay in the town square with a note pinned to it. "The paper said he had been a government spy and warned people not to move him. No one did," he said"' (Constable \& Khan, 2009).

It was clearly anticipated in the leading press front pages that Swat is just a "rest stop" and militancy will sweep in Punjab for Taliban and Taliban also gave such statements that they will grab other areas. The fall of Buner that was just 70 miles away from Islamabad, was the story that startled Pakistani and American officials, and the leading press in almost every story after the fall of Buner said that militants are just 60 miles away from Islamabad. Under domino effect, the leading printed press is in an extreme hurry to tell Americans that Islamabad is close to being conquered by the militants. It is depicted that the Taliban have captured Buner next, they will seize Mardan, Swabi, Mingora, Tarbela dam and finally, Margalla hills will only be in their way to reach 


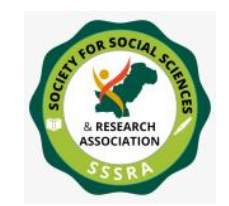

Pak. Journal of Int'L Affairs, Vol 4, Issue 3 (2021) Social Issues of Pakistan: Narrative of the U.S. ...

Islamabad where Pakistan has kept its nuclear arsenal in the south. The specter of Taliban militancy was heightened to the extent that The Washington Post's front page story published on May 5, 2009, quoting a national testimonial of Pakistan-Former interior minister of Pakistan, Aftab Sherpao-writes that Taliban are preaching on T.V. (see, Constable, 2009c) but which T.V. channel is owned by Taliban is not mentioned. The story further says that the Taliban want to turn Pakistan into an "Islamic emirate" (Constable, 2009c).

\subsection{2: Taliban-Pakistan Army Nexus: Pakistan is Ready for Revolution}

Another front-page story of The Wall Street Journal-titled as 'Pakistani Peace Deal Gives New Clout to Taliban Rebels' published on April 14, 2009-publishes the statement of a principal of private girls' school in Mingora as: "We used to have lots of cultural and extracurricular activities in the school, but all that has been stopped ... "We do not want to give any pretext to the Taliban to shut the school again" (Hussain \& Rosenberg, 2009). The depiction of these horrific scenes is critical under Morelli's propaganda principles because these frames help to win public opinion in the American war against the brutal forces.

According to the leading press, the police are afraid of the Taliban as it is reported that, "The police have become so afraid that many officers have put the advertisement in the newspapers renouncing their jobs so the Taliban will not kill them." The New York Times writes that since the Taliban made a truce and fought the military, they have clarified "who is in charge" (Perlez \& Shah, 2009). An image is portrayed in the leading press that law enforcement institutions are neither willing nor have support from the government to control these militants. The top media outlets quoted the statement of Senator Jack Reed, a Rhode Island Democrat on the Armed Services Committee said that "illustrates there is a lack of political will in the Pakistan civilian leadership to confront these Pakistan Taliban" (see, Gall \& Schmitt, 2009).

The Mainstream American printed press frames the issues to make Americans and global policy makers believe that Pakistani worsening law and order situation has been failed to control these militants as militancy in Punjab in growing under the nose of the army, law enforcement agencies and personnel are not in the control of Pakistani government. Taliban are running a parallel government in Swat, and even the commissioner of Malakand - Javed Mohammad - was appointed on the recommendation of the Taliban, and he is helping them in growing by protecting their interests (Perlez, 2009c). The New York Times' front-page story published on April 17, 2009 writes that, "Mahboob Mahmood, a Pakistani-American lawyer and former classmate of President 


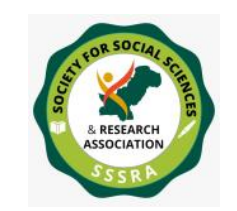

Pak. Journal of Int'L Affairs, Vol 4, Issue 3 (2021) Social Issues of Pakistan: Narrative of the U.S. ...

Obama's, said, “The people of Pakistan are psychologically ready for a revolution" (Perlez \& Shah, 2009).

\section{2: Education in Pakistan}

The front-page story of The New York Times-Islamic Schools in Pakistan Fill a Void, While Fueling Militancy-published on May 4, 2009, covers both public and Islamic education in Pakistan in full detail, and it a very long story of 1873 words (Tavernise, 2009a). We may say that as far as the coverage of public school and government's policy regarding education is concerned, the coverage is close to reality, but as far as leading press' point of view about Islamic education or the Madrassa system in Pakistan is concerned, the coverage is hugely biased and shows insufficient knowledge of the leading press about the historical and social importance of these Madrassas, Islamic Schools, in Islam and for the poor people of Pakistan. For the leading press, Madrasas are the root cause of militancy in Pakistan, and not only the Pakistani public but many politicians, along with the party members of Mian Nawaz Sharif, give donations to these schools (see, Tavernise, 2009a).

\subsection{1: Public Education and Government's Policy vs. Islamic Education}

The story starts with a pictorial depiction, "The elementary school in this poor village is easy to mistake for a barn. It has a dirt floor and no lights, and crows swoop through its glassless windows. Class size recently hit 140, spilling students into the courtyard" (Tavernise, 2009a). The story quotes Stephen P. Cohen as "This is a state that never took education seriously," said Stephen P. Cohen, a Pakistan expert at the Brookings Institution." I'm very pessimistic about whether the educational system can or will be reformed" (Tavernise, 2009a). The story further quotes Pervez Hoodbhoy-Professor of Physics at Qauaid-I-Azam University Islamabad, Pakistan-as, "Education in Pakistan was left to the dogs." It is also said that many people don't believe in the end result of education. It is very true because joblessness, nepotism, and political influence are so much that an educated man who has no influence or political link will face difficulty in finding a job. Even if he finds a job, he will be a victim of discrimination without any political backing or connections with high ups. President Obama's statement is also published in which it is said that Mr. Obama is very much concerned about the schooling system in Pakistan and announces aid for education in Pakistan (Tavernise, 2009a).

\subsection{2: Islamic Education-Madrasa system— is Fueling Jihad}




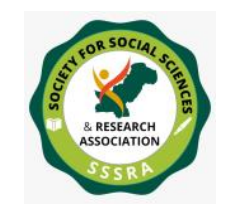

Pak. Journal of Int'L Affairs, Vol 4, Issue 3 (2021) Social Issues of Pakistan: Narrative of the U.S. ...

Tavernise's (2009a) story revolves around the Islamic education system-madrasa system-in Pakistan, and it accepts very honestly that in the 1980s "General Zia gave Madrasas money and land in an American-supported policy to help Islamic fighters against the Soviet forces in Afghanistan" (Tavernise, 2009a). The story says that practice has been going on since then, and Islamist militants and suicide bombers are being prepared in the Madrasas of Pakistan; the Madrasa system offers no education except memorizing the Quran.

It is mere hyperbole and propaganda about the Madrassa system in Pakistan because the function of Islamic schools is not just only the memorization of the Holy Qur'an. After all, it is optional, and every student of a Madrasa doesn't have the talent to memorize the Holy book. Giving a pictorial depiction of Madrasa, the story writes that, "... boys crouched over Korans, reading and rocking. A full kitchen had an industrial-size bread oven" (Tavernise, 2009a). The size of the oven amplifies the terror that militants at large number are being produced here. The New York Times' front page story published on April 14, 2009 writes that, “... When a 15-year-old boy vanished from a madrasa in a village near here recently -- his classmates said to go on jihad -- his uncle could not afford to go look for him, let alone confront the powerful men who run the madrasa" (Tavernise, Jr., \& Schmitt, 2009). By telling powerful depicts on one side that Pakistani government is on the back of these people and on the other side Pakistani public, and Madrassa is doing nothing just supplying militancy for Jihad.

These schools in Pakistan have their own education board and offer degrees like Dars-e-Nizami, M.A. Arabic, M.A. Islamic studies, specialization in Sharia, Fiqh, and Hadith. But the dilemma is that these schools are only for the poor of the poorest because a large majority of Pakistanis want their kids to be enrolled in public schools, English medium schools, or Elite schools. Giving an inaugural address in the Seminar on Global Terrorism: Genesis, Implications, Remedial, and Countermeasures jointly organized by the Institute of Regional Studies and Hanns Seidel Foundation, Munich, in Islamabad on 2931August 2005, former President of Pakistan General Musharraf said, "For everyone, Madrasa has become quite a maligned word all over the world. Madrassa has a positive and negative part." The President explained the positive aspect of Madrassa, is like an NGO which provides free boarding and "lodging to the poorest of the poor. One million, roughly, students there are getting free board and lodge. The government certainly cannot look after them" (Musharraf, P., 2005). The negative aspects, according to the President, were two, that some Madrassas indoctrinate the minds of the youth and some in tribal areas are producing terrorists, and the other negative point is that they are only teaching religion (Musharraf, P., 2005). But for the very story, the Madrassa system is a "red alert for Pakistan," and it quotes a local testimonial who says, "We are at the beginning of a great 


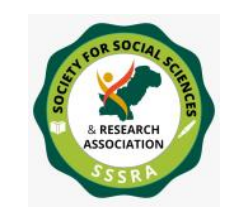

Pak. Journal of Int'L Affairs, Vol 4, Issue 3 (2021) Social Issues of Pakistan: Narrative of the U.S. ...

storm that is about to sweep the country" (Tavernise, 2009a). The agenda of the printed press is to create fear and bone-chilling effect to whip people to make them believe that whatever the U.S. is doing in Pakistan and Afghanistan is for the betterment, safety, and security of world peace.

\subsection{3: Inept, Faulty, and Contradictory reporting on Pakistan}

Reporting on such sensitive issues requires deep first-hand knowledge and understanding of the psyche of the society, but newspapers don't have much time, and creating sizzle in the story brings money. But in the background of all this propaganda, the actual responsibility of the press remains absent. Instead, it keeps focus on the agenda of the administration who, says that insurgency is shifting to Punjab, but the same newspaper and the same reporter has said before - on May 3, 2009_one day before publishing this very story - that lush green plains of Punjab and its highways are as smooth as in "American Midwest" but it had very trickily given a clue there that insurgency is underground (Tavernise, 2009b) there and after one day this underground insurgency will become a "red alert for Pakistan" (Tavernise, 2009a). This is called real propaganda based on scanty knowledge. Still, it serves well to terrify the typical American who is very innocent about International affairs and extremely terrified with Islam after witnessing the tragic incident of 9/11. So the question is that is the leading American press-enchanter of social responsibility—sincere to its public or its profession?

\section{3: Issues of Human Rights in Pakistan:}

\subsection{1: Kiln Workers in Pakistan}

Among the three leading press, The Washington Post is the only newspaper that raised the issue of miserable kiln workers in Pakistan by publishing a front-page story titled as 'Pakistan's Kiln Workers Bricked In by Debt; Families on Ancient Assembly Lines 'Can Never Earn Enough to Leave' dated July 3, 2009 (Constable, 2009a). The paper did a real good job under social responsibility theory by giving the exact details of the suffering of kiln workers and their exploitation by the influential people in Pakistan who have strong links with the politicians. This story is indeed a black mark on Pakistan's social setup.

\subsection{2: "Draconian" Hudood Ordinance}

Constable (2009b) writes that laws of the Hudood Ordinance are "draconian" and overzealous application of Sharia and are applied with force in which women are the greatest sufferer. The paper writes that "if a woman tried to accuse a man of rape, she often 


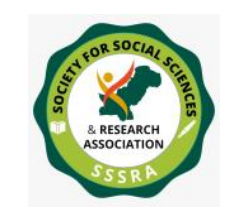

Pak. Journal of Int'L Affairs, Vol 4, Issue 3 (2021) Social Issues of Pakistan: Narrative of the U.S. ...

ended up being found guilty of adultery and punished severely, while the man went free for lack of evidence." Although the story took the expert opinion of Islamic scholars like Professor Khurshid Ahmed Raja Zafar-ul- Haq on the subject the dominant theme of and agenda of the story is no different than the misery stories of Cuban women of 1898.

\subsection{3: Women are the Most Miserable Creature in Pakistan}

Women are depicted as the most miserable creature in Pakistani society, and the reason is Islam because the Taliban are also punishing women, they are not allowed to go out without male blood relative, they cannot have affairs if they will then will be flogged like the FATA girl, dating is not allowed, the concept of urban women is not welcoming in Pakistan, Pakistan is an oppressed society, a real symbol of the Sunni version of Islam. American people value human liberty a lot, and such coverage of Pakistan is enough to rouse opposite emotions; thus public will be with the U.S. government being a follower of the "white man's burden" philosophy that always stood against tyrants since Revolution and fought against General Butcher, Hun, Kiaser, Hitler, Red Scare, Saddam, and now Taliban and Al Qaeda in Pakistan.

\section{4: Art and Pakistan:}

\subsection{1: Pakistani Society is Inhospitable to Free Expression}

The New York Times' front-page story-Contradiction Remains Vital to Pakistan and Its Art - on September 3, 2009, says that "Pakistan's reputation in the contemporary art world has often suffered from a simplistic conception that it is a society inhospitable to free expression" (Kennedy, 2009). Freedom of speech and expression are jewel-like qualities that are very close to America's heart. Anything thing against these values will be considered oppression and will definitely get media coverage and, of course, the attention of the American people.

The front-page story says that "during several periods in the country's 52-year history its visual arts, theater and film have been hemmed in by restrictions imposed under sharia, or Islamic law, and under military rule" (Kennedy, 2009). This story is basically covering an art exhibition arranged by Pakistani artists of NCA, Lahore in America. The paper says that artwork discusses complex issues like religion, political oppression, and status of Muslim women, and open depiction of "sexual imagery" is not easy in Pakistan because the Pakistani public and the parents of the art workers' don't like it. 


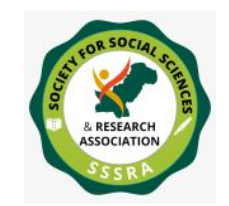

Pak. Journal of Int'L Affairs, Vol 4, Issue 3 (2021) Social Issues of Pakistan: Narrative of the U.S. ...

The paper further says that Pakistani art is drifting away from Pakistani soil, but it is being recognized in the world. Pakistani artists have strong hope for Pakistan. Kennedy (2009) quotes an artist-Huma Malji-who describes Pakistan as a place existing, "300 years in the past and 30 years in the future." It means that Pakistan is progressing and has a vision, it is a futuristic country, but it cannot forget its values, culture, traditions. With few exceptions, art is mostly the representation of values and culture in which an artist grows, and it also depends on the mentality of the artist as well and its background. Art is an imitation of imitation and personal thinking about the subject and society. Every society has its own values. But it may be difficult for the American people or press to think because "American Internationalism" is very important, i.e., what is good for America should be good for others. Former President General Musharraf said that we cannot change; we can only transform (Musharraf, P., 2005). The U.S. and its press must understand the voice of Pakistan.

\subsection{2: Pakistanis are Homosexuals, but they Don't Accept Openly like Indians}

The New York Times' front-page story-Pakistani Artists Find a Contemporary Voice'-published on September 29, 2009, focuses on a teacher of the National College of Arts, Lahore, whose primary focus of artistic expression is on homosexuality and gayism (Perlez, 2009b). The leading paper quotes the teacher as, "Pakistan, where homosexuality is recognized as a part of life in many extended families, but is barely accepted in public discourse" and showing the bold homosexual artistic expression in Pakistan is not easy (Perlez, 2009b). The paper further quotes the teacher as, "No one would have the courage to show it here -- it's too explicit," he said, adding that he had recently sold a large acrylic with explicit homosexual imagery to a well-to-do young collector who will hang it in his Karachi home" (Perlez, 2009b). This is an absurd kind of reporting. Such reporting has got no connection with the majority of Pakistanis. This kind of narrative is against the ideology of Pakistan and does not match with the living style of people in Pakistan.

Comparing Pakistan to India, it is said that homosexuality is much accepted there as he (the Pakistani teacher of art at NCA, Lahore) told The New York Times that Mumbai gallery has "recently selected 14 pages for an exhibition ... "The safer ones," Mr. Saeed said wryly" (Perlez, 2009b). The word "safer" shows the artistic insanity and pornographic tendency of the artist/teacher, and the word "wryly" clearly indicates that even India, where it is said that homosexuality is accepted, has selected only that work of the artist, which is safe. Generalizing the ideas of a single artist as a whole Pakistani psyche is no moral and ethical service of the leading press. Instead, it will again serve the function that Pakistan is a very oppressed society under the influence of religion that does not allow people to voice their voice. 


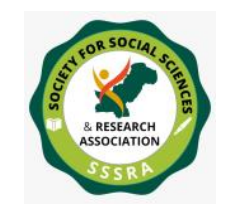

Pak. Journal of Int'L Affairs, Vol 4, Issue 3 (2021) Social Issues of Pakistan: Narrative of the U.S. ...

\subsection{3: Pakistani Society is Deeply Rooted in Values}

Huma Malji has already said that Pakistan is a society that is deeply rooted in its values (Perlez, 2009b). This is why people at a significant level don't accept such things even pious Christians or Jews don't like it. The paper also quotes Bani Abdi-a graduate of Art Institute of Chicago - who says that "the United States ... had pushed Pakistan into falling line with the war on terror, regardless of potential fall out" and her artwork was an anthem based on, "discordant alliance between the two countries" (Perlez, 2009b). Bani Abdi is not a graduate of any Madrasa in Pakistan but she is an American graduate; probably nobody indoctrinated her. But she is an artist; being sensitive, she chooses the words like "discordant alliance" and these words are self-explanatory. The U.S. and the West must understand the soul of these two words in the context of Pakistani values; hopefully, things will be better, but for this, America should reconsider doctrines like "Unilateralism" and "American Internationalism." American "Unilateralism" and

\section{5: Discussion and Conclusion}

From January 2009 to January 2010, the coverage pattern of front-page stories of the mainstream American printed press about Pakistan revolves around political, religious, moral, and security narrative. The leading press presents the picture of Pakistani social issues as it is a society "inhospitable to free expression," issues of human rights in Pakistan are draconian, education in Pakistan is left to the dogs, madrasas (religious schools) are supplying militancy for Jihad, law and order situation in Pakistan is worsening. The leading press is building a narrative about Pakistan that the world's safety is at stake because of Pakistan - a nuclear-armed Muslim country.

The mainstream American printed press-liberal and conservative - is creating a picture in American heads that Pakistan is one of the most corrupt countries globally and is an "incubator of militants." The coverage is highly graphic and dipped in horror. Fear ceases the power of thinking. The American public has already witnessed the tragic incidents of $9 / 11$. Using the twin towers' images and WOT narrative and pictures in our heads, the mainstream U.S. printed press is developing a narrative that those who did 9/11 may hit America again. To stop such an act, WOT is necessary in which Pakistan should have to play a critical role at any cost. Hence the message is that deal Pakistan with iron hands.

Following the official American line that the WOT is not a choice but a necessity, the mainstream media is framing the social issues of Pakistan with a tilt that Pakistanis 


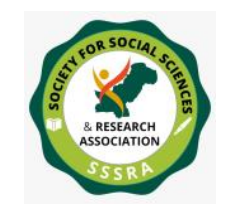

Pak. Journal of Int'L Affairs, Vol 4, Issue 3 (2021) Social Issues of Pakistan: Narrative of the U.S. ...

lack the social and political will to confront Taliban and anti-human forces. Nonetheless, their Islamic ideology, religious schooling system, and army fuel Jihad. For the mainstream American press, the people of Pakistan are ready for revolution. Such a coverage reinforces the thought of Lowenthal (1961), who says, "The most direct and composite experience of the world is a composite of perception, memory, logic and faith." Under specific agenda, the American printed press is trying to win people's faith that Pakistan is the most dangerous country in the world, so the U.S. led WOT is legitimate in the Afghanistan-Pakistan region.

"American Internationalism" sets American foreign policy, and American media sets its agenda accordingly to build a narrative to defeat the enemy country in the public sphere. Presidential candidate Joe Biden's friendship campaign with American Muslims in 2020 seems a reaction and rhetoric and a mere political campaign to undermine President Trump's legitimacy among American Muslims to win their vote and support. Lifting a Muslim ban will not help to improve America's relations with the Muslims inside and outside America and the Muslim world. Structural changes are required in the American education system - especially at the school level - to make a good image of Muslims in the mind of an American kid. The American mainstream printed and electronic media also need to play its role in peace journalism. Media-liberal and conservative - in the U.S. should not fuel conflict and stereotypes by portraying the negative image of Muslims. When Trump says that the press in America is the enemy of people, he talks about how media is creating negativity, bigotry, and racial superiority in American people about others and making them a war-loving nation that people usually are not because people love peace, not conflict. American people are also no exception. The majority are peaceloving people, but the media is making them war crazy. The coverage of the social issues of Pakistan on the front page of the mainstream American press from January 2009 to January 2010 shows that the press is not doing service to humanity and America; instead, it is playing in the hands of hidden powers who have ulterior agendas for personal gainswealth, power, and control. 
Pak. Journal of Int'L Affairs, Vol 4, Issue 3 (2021) Social Issues of Pakistan: Narrative of the U.S. ...

\section{REFERENCES:}

American Foreign Relation. (2021). Public Opinion - Presidential powers. Retrieved from https://www.americanforeignrelations.com/O-W/Public-Opinion-Presidentialpowers.html

Arts, N. C. o. E. f. t. C. (1982). NCECA Journal: The Council.

Beattie P. (2019). The Transition: Information from Media to Mind. In: Social Evolution, Political Psychology, and the Media in Democracy. Palgrave Macmillan, Cham. https://doi.org/10.1007/978-3-030-02801-5_5

Beattie, P. (2019). Social evolution, political psychology, and the media in democracy: The invisible hand in the U.S. marketplace of ideas.

Braun, V., \& Clarke, V. (2006). Using thematic analysis in psychology. Qualitative research in psychology, 3(2), 77-101.

Constable, P. (2009a, July 3, 2009). Pakistan's Kiln Workers Bricked In by Debt; Families on Ancient Assembly Lines 'Can Never Earn Enough to Leave.' The Washington Post, p. A1.

Constable, P. (2009b, May 10, 2009). Taliban-Style Justice Stirs Growing Anger; Sharia Being Perverted, Pakistanis Say. The Washington Post, p. A1.

Constable, P. (2009c, May 5, 2009). The Taliban Tightens Hold In Pakistan's Swat Region. The Washington Post, p. A1.

Constable, P., \& Khan, H. N. (2009, May 11, 2009). Fear and Worry Pervade Refugee Camps As Pakistanis Flee Assault on Taliban. The Washington Post, p. A1.

Dearing, J. W., \& Rogers, E. M. (1996). Agenda-Setting doi:http://dx.doi.org/10.4135/9781452243283.n1 
Pak. Journal of Int'L Affairs, Vol 4, Issue 3 (2021) Social Issues of Pakistan: Narrative of the U.S. ...

DeYoung, K. (2009a, November 30, 2009). U.S. offers new role for Pakistan; A broader partnership Importance of country to Afghan effort recognized. The Washington Post, p. A1.

DeYoung, K. (2009b, May 4, 2009). U.S. Options in Pakistan Limited; Nation Rife With Security Issues, Infighting, Anti-American Sentiment. The Washington Post, p. A1.

DeYoung, K., \& Wilson, S. (2009, October 8, 2009). Pakistanis Balk at U.S. Aid Package; Criticism Threatens To Snarl Obama's Efforts in Region. The Washington Post, p. A1.

Eisinger, R. M., Veenstra, L. R., \& Koehn, J. P. (2007). What media bias? Conservative and liberal labeling in major US newspapers. Harvard International Journal of Press/Politics, 12(1), 17-36.

Gall, C., \& Schmitt, E. (2009, April 24, 2009). U.S. Questions Pakistan's Will To Stop Taliban. The New York Times, p. A1.

Gillani, A., \& Zhou, X. (2015a). Is Pakistan Terrorist? Front-page Perspective of Mainstream American Newspapers during Obama's First-year. New Media and Mass Communication, 40, 87-111.

Gillani, A., \& Zhou, X. (2015b). News or Weapons of Mind Destruction: Press in America from Colonies till Obama. Research on Humanities and Social Sciences, 5(20), 5066.

Grant, C. (1998, May 7). Fridays and 13ths: Luck or superstition? Seminar presented at the meeting of the American Cultural Society, Tacoma, WA.

Hussain, Z., \& Rosenberg, M. (2009, April 14, 2009). Pakistani Peace Deal Gives New Clout to Taliban Rebels. The Wall Street Journal, p. A1.

Jia, W., \& Lu, F. (2021). U.S. media's coverage of China's handling of COVID-19: Playing the role of the fourth branch of government or the fourth estate? Global Media and China, 6(1), 8-23.

Jr., R. A. O., \& Shah, P. Z. (2009, January 25, 2009). In Pakistan, Radio Amplifies Terror of Taliban. The New York Times, p. A1. 
Pak. Journal of Int'L Affairs, Vol 4, Issue 3 (2021) Social Issues of Pakistan: Narrative of the U.S. ...

Kennedy, R. (2009, September 3, 2009). Contradiction Remains Vital To Pakistan And Its Art. The New York Times, p. A1.

Khalid, A. (2020). Presidential Nominees Rarely Speak To Muslim Audiences. Biden Did Monday. Retrieved from https://www.npr.org/2020/07/20/893066503/presidentialnominees-rarely-speak-to-muslim-audiences-biden-did-monday

Khan, M. A. (2008). The image of Pakistan in prestigious American newspaper editorials: A test of the media conformity theory. Strategic Studies, 105-128.

Lieten, G. (2008, Autumn). Pakistan, an abundance of problems and scant knowledge. IIAS Newsletter, 49, 3.

Lippmann, W. Public Opinion (1922).

Lowenthal, D. (1961). Geography, experience, and imagination: towards a geographical epistemology. Annals of the Association of American Geographers, 51(3), 241-260.

Lowndes F. Stephens (2013). Mass Media and Terrorism - Debates continue over role of media in coverage of terrorism. In Margaret A. Blanchard (Ed.) History of the Mass Media in the United States: An Encyclopedia (pp. 367-369). Routledge.

Lumet, S. (Writer). (1976). Network.

McCombs, M. E., \& Shaw, D. L. (1972). The agenda-setting function of mass media. Public Opinion Quarterly, 36(2), 176-187.

Mirza, M. N., \& Mushtaq, N. (2019). Pak-US relations: Transactional-transformational debate. Journal of Security and Strategic Analyses, 5(2), 27-49.

Moeller, S. D. (2007). The" good" Muslims: U.S. Newspaper Coverage of Pakistan: International Center for Media and the Public Agenda, University of Maryland.

Musharraf, P. (2005). Global Terrorism: Genesis, Implications, Remedial, and Countermeasures. Seminar jointly organized by the Institute of Regional Studies and

Hanns Seidel Foundation, Munich, in Islamabad on 29-31 August 2005. Baker, C. E. (1998). The media that citizens need. University of Pennsylvania Law Review, $317-$ 408. 
Pak. Journal of Int'L Affairs, Vol 4, Issue 3 (2021) Social Issues of Pakistan: Narrative of the U.S. ...

Perlez, J. (2009a, February 17, 2009). Pakistan Makes a Taliban Truce, Creating a Haven. The New York Times, p. A1.

Perlez, J. (2009b, September 25, 2009). Pakistani Artists Find a Contemporary Voice. The New York Times, p. A1.

Perlez, J. (2009c, April 23, 2009). Taliban Seize Pakistan Area Nearer Capital. The New York Times, p. A1.

Perlez, J., \& Shah, P. Z. (2009, April 17, 2009). Taliban Enlist an Army of Pakistan's Have-Nots. The New York Times, p. A1.

Pew Research Center. (2017). U.S. Muslims Concerned About Their Place in Society, but Continue to Believe in the American Dream - Findings from Pew Research Center's 2017 survey of U.S. Muslims. Retrieved from https://www.pewforum.org/2017/07/26/findings-from-pew-research-centers-2017survey-of-us-muslims/

Pintak, B., \& Albright. (2019, March 13). Islamophobes Came for Americans on the Campaign Trail. Foreign Policy. Retrieved from https://foreignpolicy.com/2019/03/13/islamophobes-came-for-americans-on-thecampaign-trail/

Rosenberg, M., \& Hussain, Z. (2009, February 26, 2009). Pakistan's Leader Stirs Fresh Turmoil. The Wall Street Journal, p. A1.

Roßmann, M. (2021). Vision as make-believe: how narratives and models represent sociotechnical futures. Journal of Responsible Innovation, 8(1), 70-93.

Sparrebom, M. (2008, Autumn). Director's note. Pakistan Newsletter, p. 48. Retrieved from https://www.iias.asia/sites/default/files/theNewsletter/2019. 06/IIAS_NL49_FULL.pdf

Tavernise, S. (2009a, May 4, 2009). Islamic Schools in Pakistan Fill a Void, While Fueling Militancy. The New York Times, p. A1.

Tavernise, S. (2009b, May 3, 2009). Struggling To See A Country Of Shards. The New York Times, p. A1. 
Pak. Journal of Int'L Affairs, Vol 4, Issue 3 (2021) Social Issues of Pakistan: Narrative of the U.S. ...

Tavernise, S., \& Gillani, W. (2009, August 6, 2009). 70 Murders, Yet Close to Going Free in Pakistan. The New York Times, p. A1.

Tavernise, S., Jr., R. A. O., \& Schmitt, E. (2009, April 14, 2009). United Militants Threaten Pakistan's Populous Heart. The New York Times, p. A1.

TEACHING THE MIDDLE EAST - A RESOURCE FOR EDUCATORS. (2010a, December 29, 2010). Defining "Stereotype." Retrieved from http://teachmiddleeast.lib.uchicago.edu/historical-perspectives/middle-east-seenthrough-foreign-eyes/islamic-period/framing-the-issues/issue-02.html

TEACHING THE MIDDLE EAST - A RESOURCE FOR EDUCATORS. (2010b, December 29, 2010). Public Opinion Data. Retrieved from http://teachmiddleeast.lib.uchicago.edu/historical-perspectives/middle-east-seenthrough-foreign-eyes/islamic-period/framing-the-issues/issue-01.html

U.S. offers new role for Pakistan; A broader partnership Importance of country to Afghan effort recognized. The Washington Post, p. A1.

Winnick, T. A. (2019). Islamophobia: Social Distance, Avoidance, and Threat. Sociological Spectrum, 39(6), 359-374.

Wonacott, P. (2009, January 6, 2009). For Middle-Class Pakistanis, A Gun Is a Must-Have Accessory--- With Kidnappings and Violence on the Rise, Demand for Weapons Permits Grows The Wall Street Journal, p. A1. 